\title{
Influence of Different Geomorphic Surfaces and Profile Modification on the Growth of Maesopsis eminni (Engl) at the Yongka Western Highlands Research Garden Park Nkwen-Bamenda, North West Cameroon
} \author{
Nicole Guehjung ${ }^{3}$, Grace Mbakpor Ayuk ${ }^{3}$ \\ ${ }^{1}$ Department of Soil Science, University of Dschang, Dschang, Cameroon \\ ${ }^{2}$ Ministry of Agriculture and Rural Development, West Region, Cameroon \\ ${ }^{3}$ Department of Crop Production, University of Dschang, Dschang, Cameroon \\ Email: ^bernardyerima@yahoo.com
}

Bernard Palmer Kfuban Yerima ${ }^{*}$, Roger Kogge Enang1, Claude Assembo Makem²,

How to cite this paper: Yerima, B.P.K., Enang, R.K., Makem, C.A., Guehjung, N. and Ayuk, G.M. (2017) Influence of Different Geomorphic Surfaces and Profile Modification on the Growth of Maesopsis eminni (Engl) at the Yongka Western Highlands Research Garden Park Nkwen-Bamenda, North West Cameroon. American Journal of Plant Sciences, 8, 69-84. http://dx.doi.org/10.4236/ajps.2017.81006

Received: December 20, 2016

Accepted: January 15, 2017

Published: January 18, 2017

Copyright $\odot 2017$ by authors and Scientific Research Publishing Inc. This work is licensed under the Creative Commons Attribution International License (CC BY 4.0).

http://creativecommons.org/licenses/by/4.0/

\begin{abstract}
The growth of Maesopsis under the influence of various geomorphic surfaces was followed within a period of 70 months. Young plants of two months old were transplanted into $70 \times 70 \times 70 \mathrm{~cm}$ holes under natural conditions (no inputs such as manure and other amendments). A randomized complete block design was set up for the experiment, alongside a control, and growth parameters followed (height and collar circumference). Three blocks with different geomorphic surfaces were put in place for the experiment (upper slope or block 1, middle slope or block 2 and foot slope or block 3). Results of the experiment indicated that geomorphic surface had a significant effect on height but not on collar circumference. Plant height increased progressively from upper slope to foot slope; less tall trees were found at the upper slope, while the tallest trees were found at the foot slope. After 70 months, maximum average height attained by plants for the experiment was $1228.3 \mathrm{~cm}$, observed in block 3 (foot slope), significant at 0.05 confidence level with respect to geomorphic surface. In blocks 1 and 2 (upper slope and middle slope), maximum average heights attained were 798.5 and $937.5 \mathrm{~cm}$, respectively and were shown to be statistically equal at 0.05 confidence level. Geomorphic surface had no effect on collar circumference. Maximum average collar circumferences attained after 70 months were $62.8 \mathrm{~cm}$ (observed at the upper slope), $61.3 \mathrm{~cm}$ (observed at the middle slope) and $76.3 \mathrm{~cm}$ (observed at the foot slope) and the various collar circumferences were shown to be statistically the
\end{abstract}


same at 0.05 confidence level. For the control, maximum height attained after 70 months was $1240 \mathrm{~cm}$ (observed at the foot slope). At the upper slope and middle slope, maximum average heights were respectively, $800 \mathrm{~cm}$ and 905 $\mathrm{cm}$, and were statistically equal at the 0.05 confidence level but different from the foot slope value of $1240 \mathrm{~cm}$. Maximum average collar circumference was observed at the foot slope $(76.3 \mathrm{~cm})$, while circumferences of $62.8 \mathrm{~cm}$ and 61.3 $\mathrm{cm}$ were respectively observed at the upper and middle slopes. In the control, collar circumference was shown to be statistically equal at the upper and middle slopes but different from that at the foot slope at 0.05 confidence level. Correlations between growth parameters were more explained for the control than for the experiment. Increasing plant height was associated with decreasing percent slope (at a p-value of 0.05 ) corresponding to increasing soil depth favoring root exploration and soil and water retention. Profile modification enhanced plant growth and enabled the cultivation of trees on all geomorphic surfaces.

\section{Keywords}

Maesopsis, Upper Slope, Middle Slope, Foot Slope, Height, Collar

Circumference, Profile Modification, Induced Hydrolysis

\section{Introduction}

Watershed management and protection of degraded environments are posing many challenges in the Western Highlands of Cameroon [1]. Selection of appropriate plant species and appropriate plant husbandry practices to enhance plant growth is equally a challenge.

It is necessary that watershed protection be done with plants that are fast growing, have limited transpiration rates, and have some immediate economic value to the farmers planting them in the watershed to enhance its adoption. Maesopsis eminni (Engl), because of its many advantages meets this requirement.

Maesopsis eminni (Engl) has a wide range of uses. It is widely used in agroforestry [2] and also serves as a biofertilizer [3]. It provides shade to many crops and the leaves are used for fodder [4]. Economically, Maesopsis provides timber for furniture making and local construction due to its excellent mechanical properties [5] [6]. Due to its fast growth, M. eminii is widely planted for fuel wood [4]. Aesthetically, Maesopsis is used as an ornamental tree [7]. In Bamenda (North West region of Cameroon), the Blue moon watershed is protected with Maesopsis. Maesopsis contributes enormously to biodiversity conservation; many insect and bird species visit the tree and spend much time on it, even using it as their shelters. Birds are attracted to the tree by the fruit pulp when ripe. Common bird species found on Maesopsis in Mankon (North West region of Cameroon) include: Bamenda apalice (Apalis bamendae), Green turaco (Turaco perro), Black-billed weaver (Ploceus melanogaster), Bannerman's weavers (Plo- 
ceus bannermani), Sun birds (Nectarinia sp.), and Speckled Mouse birds (Colius straitus). Many ant species visit the tree for its bark, leaves and fruit juice. Commercially, the cotyledons are sold for their oils and fruits have colorant matter (from oxidation of oils) used for art works [7] [8]. M. eminni is widely used in medicine; the root bark is used to treat gonorrhea [9], and serves as a diuretic for ascites [10]. It is also used as abortifacient [11]. In Nigeria, the bark is used to solve constipation and painful menstruation problems [12]. Maesopsis is also used as a diuretic and purgative for "yellow fever" [13].

Some compounds isolated from Maesopsis have exhibited some interesting biological activities; for example, lupeol has been shown to exhibit hypotensive activity [14], in vitro anti-malarial activity [15], as well as anti-inflammatory activity [16]. Sitosterol and stigmasterol, isolated from the bark of Maesopsis were found to be essential starting materials in pharmaceutical industries where they are used in the manufacture of steroidic drugs [17]. Because of the presence of triterpenoids in Maesopsis, the plant can act as a potential source of drugs with the following physiological activities: antitumour and anticancer activity, antiinflammatory activity, action on metabolism, antimicrobial activity, effect on biosynthesis and molluscicidal activity [17]. Two pentacyclic triterpenes, $1 \alpha, 3 \beta$ dihydroxybauer-7-en-28-oic acid and 3 $\beta$-hydroxybauer-7-en-28-oic acid, together with sitosterol-3- $\beta$ - $O$-d-glucopyranoside and stigmasterol, isolated from the bark of $M$. eminii have displayed moderate antibacterial activity against $\mathrm{Ba}$ cillus subtilis ATCC 6633 [18].

The above uses of Maesopsis clearly indicate that vulgarization of the plant is very important and needs to be encouraged. However, the steep sloping and granitic nature of certain areas, especially the western highlands of Cameroon, which have compact (Figure 1) and very shallow soils (Figure 2) have hampered the cultivation of environmentally friendly tree species (which in most cases are multipurpose).

Secondly, given the problems associated with forest regeneration in similar areas and the need to protect watersheds or water catchment areas, such a study would guide forest regeneration efforts in the area. The growth of Maesopsis
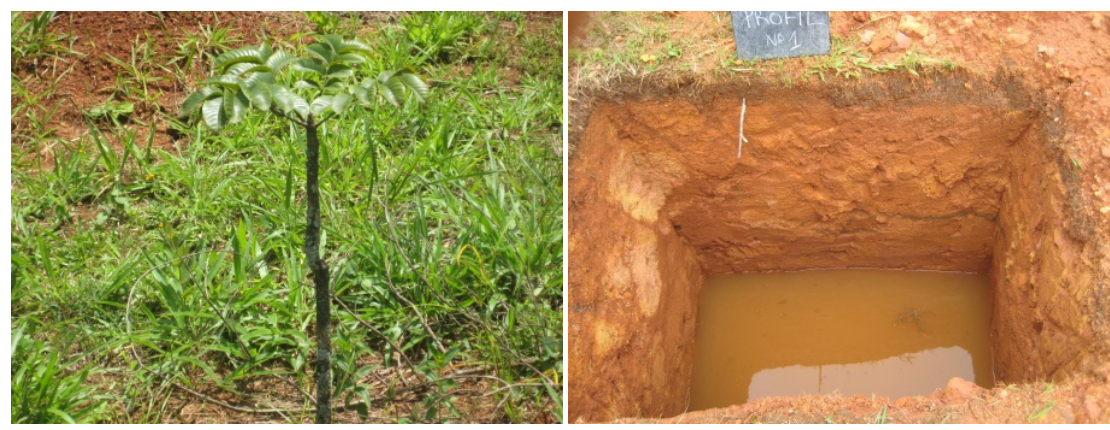

Figure 1. Left, a 15-year old mahogany tree planted in a hole measuring $30 \times 30 \times 30 \mathrm{~cm}$. Right, 20 meters from the mahogany plant, a profile dug exposing the different horizons (Water stood in profile for $>48$ hours). Note: The compact and dense nature of the horizons reduces water percolation, impedes root penetration and exploration and constraints plant development. 


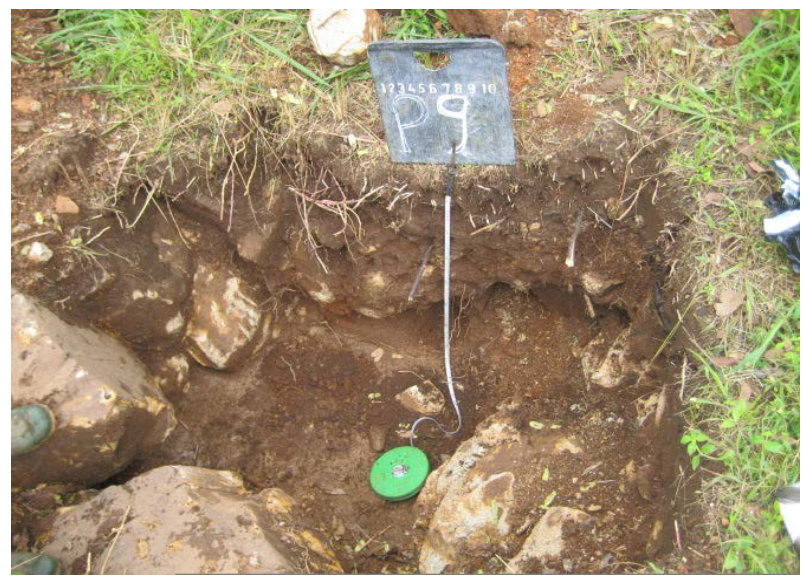

Figure 2. An entisol (a very shallow soil) that would limit root penetration and exploration.

eminii under the influence of different geomorphic surfaces subjected to the same profile modification techniques at Yongka Western Highlands Research Garden Park, Nkwen-Bamenda in the North-West region of Cameroon was studied after 70 months from the time of transplantation. The main objective was to find out if geomorphic surface has any effect on the growth parameters (height and collar circumference).

\section{Materials and Methods}

\subsection{Presentation of Study Site and Experimental Design}

The 16-year old, 4.5-ha Yongka Research Park is located at an altitude of 1200 $1400 \mathrm{~m}$, on 2 to $45 \%$ slopes in Nkwen-Bamenda in the North West Region (Long. $10^{\circ} 10^{\prime \prime} \mathrm{E}$ and Lat. $5^{\circ} 50^{\prime \prime} \mathrm{N}$ ) (Figure 3), a part of the Western Highlands of Cameroon.

The area has a staircase configuration dominated by high lava plateaus surrounded by steep mountains and hills, below a plateau with a steep escarpment on basement rock and more or less dissected planation surfaces. Five types of parent materials, which vary over very short distances exist in the area include: organic materials, alluvial/alluvio-colluvial deposits, colluvial deposits, mylonite and granite; granite is the most dominant. With increasing population pressure much of the natural forest vegetation has degraded to secondary formations, or has been replaced by more or less wooded grasslands and agricultural lands; this process is most advanced in areas with least relief.

Vegetation distribution at the study site can be summarized as follows: Hyperrhenia and Sporobolus grassland dominate above $1500 \mathrm{~m}$ altitude; with degraded Sporobolus replacing Hyperrhenia, while Bracken in many places is invading the grassland; Hyperrhenia and wooded savanna (below $1500 \mathrm{~m}$ ); elephant grass (Pennisetum purpureum) in seasonally flooded swamp grasslands; and spear grass (Imperata cylindrica) on fallow lands after a long period of cultivation.

The climate in the area is distinctly seasonal with one rainy season and one dry season. Rainfall at the research site averages about $2400 \mathrm{~mm}$ /year; mean 


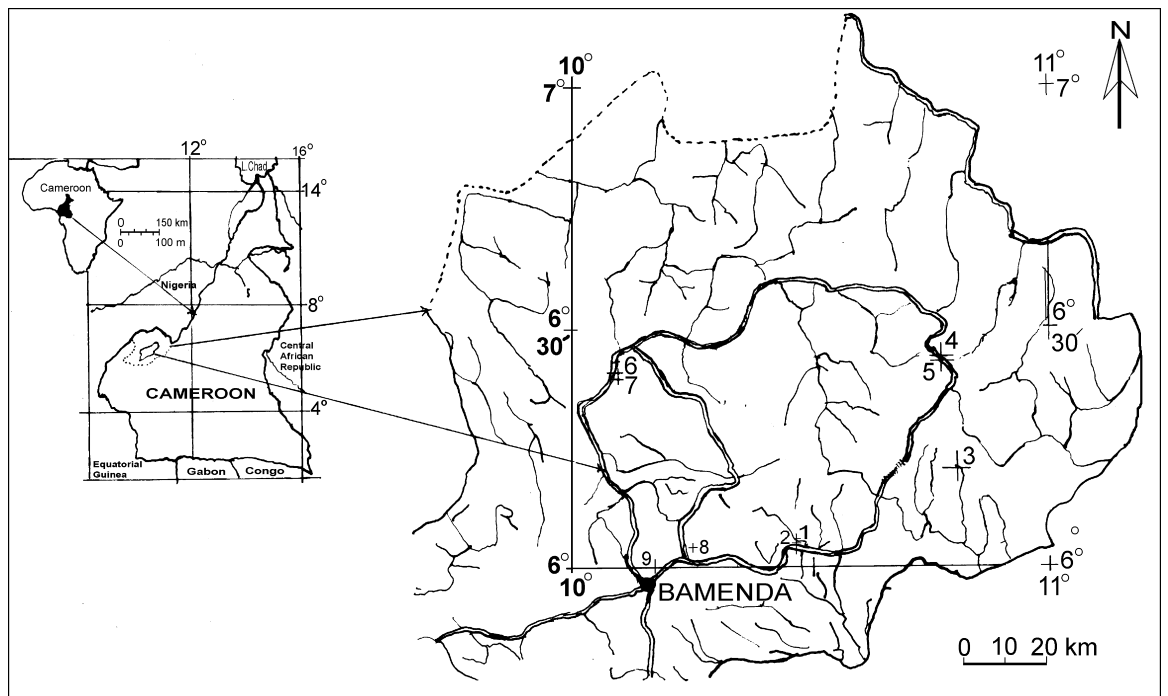

Figure 3. Map showing the study area in the west part of Bamenda town, NW Region.

annual temperatures average $19^{\circ} \mathrm{C}-22^{\circ} \mathrm{C}$.

\subsection{Characteristics of Experimental Units}

The experimental plot of $1200 \mathrm{~m}^{2}$ ( $0.12 \mathrm{ha}$ ) was divided into 3 blocks following different geomorphic surfaces; upper slope (block 1), middle slope (block 2) and foot slope (block 3).

Block 1: Geomorphic surface, upper slope; topography, flat; gradient, with a range of 2 to $10 \%$, class 1; altitude, $1304 \mathrm{~m}$; very few stones and gravel at the surface; good drainage, class 4; parent material, granite; soil covered with Chromolaena odorata and Imperata cylindrica. Soil compacted during excavation of nearby road. Presence of alluvio-colluvial materials varying from 10 to $35 \mathrm{~mm}$ in diameter transported from the granitic uplands occur at depths of $80 / 85 \mathrm{~cm}$ and $114 / 120 \mathrm{~cm}$ in the soil profile.

Block 2: Geomorphic surface, middle slope; Topography, convex slope with a range of 25 to $45 \%$, class 6; altitude, $1296 \mathrm{~m}$; drainage, slightly excessive, class 5; parent material, granite; soil covered with Chromolaena odorata.

Block 3: Geomorphic surface, foot slope; topography, undulating foot slope; with a range of 2 to $5 \%$, class 2; altitude, $1282 \mathrm{~m}$; drainage, good, class 4; parent material, alluvio-colluvial granitic deposits.

Alongside the experiment, a control was put in place with similar conditions. In the control however, soils show more similarities in properties than in the main experiment.

Also, there was a regular gradient from upslope to downslope in the control (Figure 4), with ranges of 5 to $10 \%, 10$ to $30 \%$, and 2 to $5 \%$ for the upper slope, middle slope and foot slope, respectively.

\subsection{Experimental Management}

Holes of dimensions $70 \times 70 \times 70 \mathrm{~cm}$ were dug and micro basins installed on the lower sides to increase the retention and infiltration of water. Young plants of 


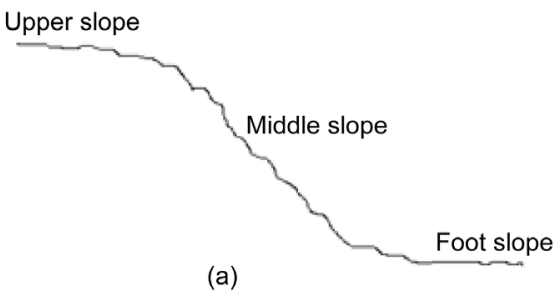

(a)

Figure 4. Geomorphic surfaces for (a) Experiment; (b) Control.

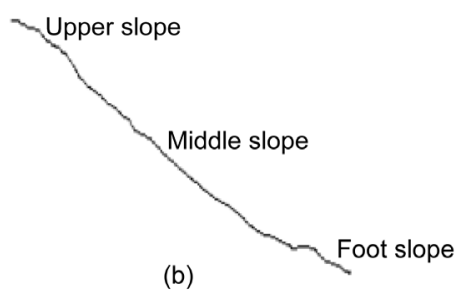

(b)

two months old were then transplanted into the holes, and mulching done during each clearing event to reduce water evaporation, while increasing nutrient content on decomposition. Recording of data was carried out from August 2007 to October 2014; a period of exactly 70 months (close to six years) during which the growth of Maesopsis was followed. Continuous mulching was made after each clearing event.

\subsection{Parameters Followed}

The growth parameters measured in the course of the experiment were height and collar circumference. Measurements were done using graduated tapes, for collar circumference, and graduated poles for height.

\subsection{Soil Sampling and Laboratory Analysis}

In each of the three blocks, a representative soil profile was dug, macromorphological features described and soil samples collected for physico-chemical analysis. Soil samples were air-dried, crushed and passed through a $2 \mathrm{~mm}$ sieve to remove fragments $>2 \mathrm{~mm}$. Sub-samples were oven-dried at $105^{\circ} \mathrm{C}$ and physicochemical analyses carried out following standard laboratory procedures as described by [19].

Routine soil characterization included ammonium acetate $\mathrm{pH} 7$ extraction of exchangeable bases, $1 \mathrm{~N} \mathrm{KCl}$ extraction of exchangeable acidity and effective cation exchange capacity (ECEC) by sum of exchangeable bases $\left(\mathrm{Ca}^{2+}, \mathrm{Mg}^{2+}, \mathrm{K}^{+}\right.$, and $\mathrm{Na}^{+}$) plus exchangeable acidity (19). Particle-size distribution, cation exchange capacity (CEC), exchangeable cations and $\mathrm{pH}$ water were determined on the fine-earth fraction [19].

Organic carbon was determined by the Walkley-Black wet oxidation method, total nitrogen by the wet digestion method, and available phosphorous by the Bray II method. The saturated hydraulic conductivity was determined by the falling-head method as described by [20].

\subsection{Statistical Analysis}

Data collected for the period of 70 months were analyzed using Microsoft Excel 2007 (mainly determination of averages of parameters and plotting of growth curves). Genstat $9^{\text {th }}$ edition, version 9.2 was used to study the effect of geomorphic surface on growth parameters, and regressions and correlations between geomorphic surface and growth parameters. 


\section{Results}

Soils differ over short distances in such characteristics as texture, effective depth, gravel content, compactness and water infiltration rates aggravated by prior cattle rearing activities. Important differences in chemical characteristics and soil fertility exist and are related to parent material and stage of soil development and would impact on forest regeneration [21]. Detailed characterization of the morpho-physico-chemical properties of the soils at the study site indicates three main soil types: Entisols (Young soils); Inceptisols (Soils with minimal development); and Oxisols (Very highly weathered soils).

The physic-chemical properties of the three profiles in each of the blocks are presented below (Table 1). After 70 months from the time of transplantation, it was observed that the growth of Maesopsis (mainly height) is greatly influenced by geomorphic surface (Table 2). As shown in Figures 5-7, overall increase in height is different in the blocks. For the parameters measured, height and collar circumference, it was observed that the maximum average height attained was $1228.3 \mathrm{~cm}$ (observed in block 3), $937.5 \mathrm{~cm}$ (observed in block 2) and $798.5 \mathrm{~cm}$ (observed in block 1) for the experiment, and $1240 \mathrm{~cm}$ (observed at the foot slope), $800 \mathrm{~cm}$ (upper slope), and $905 \mathrm{~cm}$ (mid slope) for the control. Growth rate averages indicate that plant height increases at the rate of $14.66 \mathrm{~cm} / \mathrm{month}$, $16.55 \mathrm{~cm} /$ month and $21.99 \mathrm{~cm} /$ month in blocks 1,2 and 3, respectively for

Table 1. Physico-chemical properties of soils on the various geomorphic surfaces (blocks).

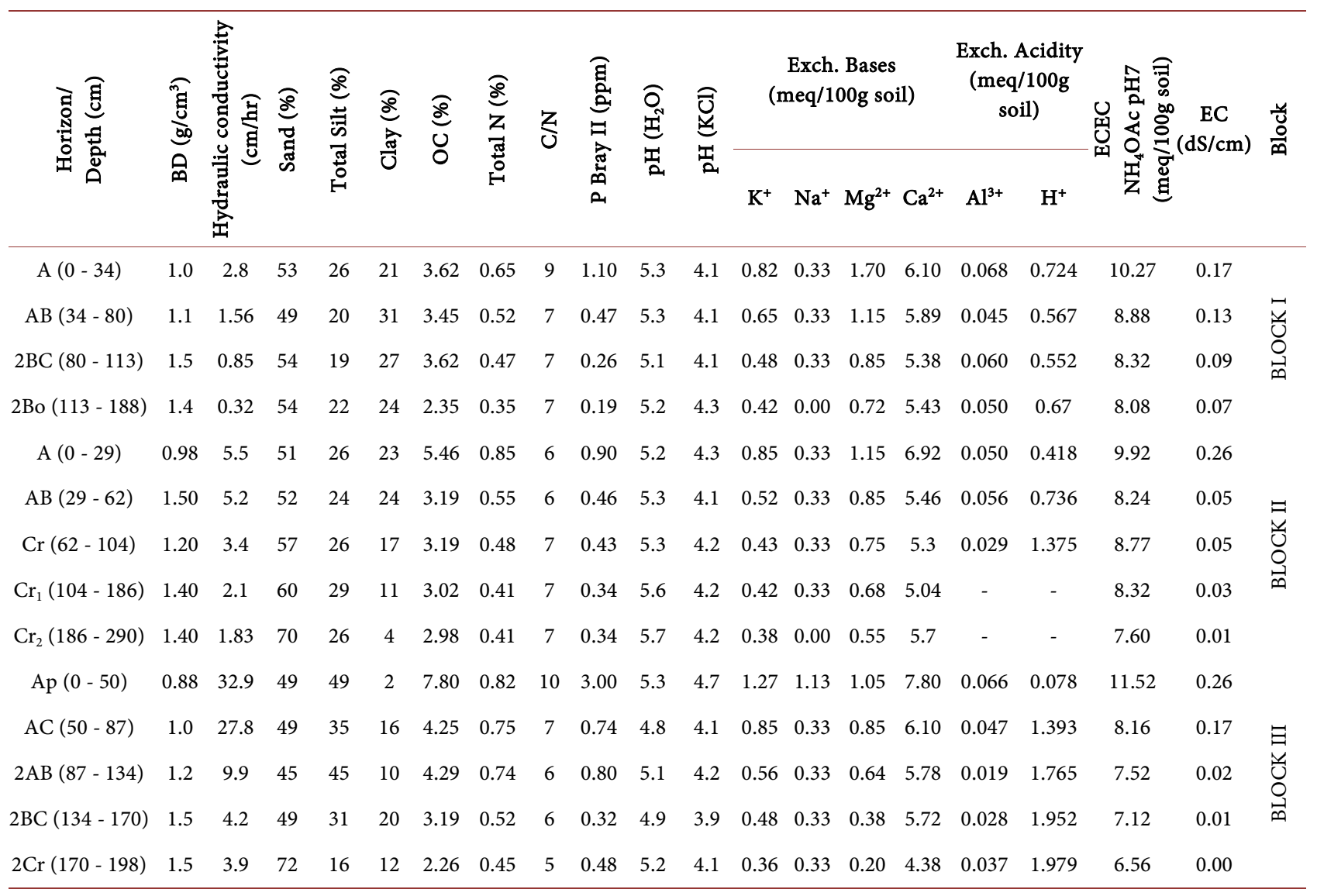


Table 2. Effect of geomorphic surface on plant height and collar circumferences.

\begin{tabular}{ccc}
\hline \multicolumn{2}{c}{ Effect of blocks (geomorphic surfaces) on total surface increase in height $(\mathrm{cm})$} \\
\hline Blocks & Experiment & Control \\
\hline 1 & $798.5(\mathrm{~b})$ & $800(\mathrm{~b})$ \\
2 & $937.5(\mathrm{~b})$ & $905(\mathrm{~b})$ \\
3 & $1228.3(\mathrm{a})$ & $1240(\mathrm{a})$ \\
\hline Effect blocks (geomorphic surface) on total increase in collar circumference (cm) \\
\hline Blocks & Experiment & Control \\
\hline 1 & $62.8(\mathrm{a})$ & $62 . .6(\mathrm{a})$ \\
2 & $61.3(\mathrm{a})$ & $60.7(\mathrm{a})$ \\
3 & $76.3(\mathrm{a})$ & $77.4(\mathrm{~b})$ \\
\hline
\end{tabular}

NB: Data are means of six plants. Means with the same letter are not significantly different at $p \geq 0.05$.

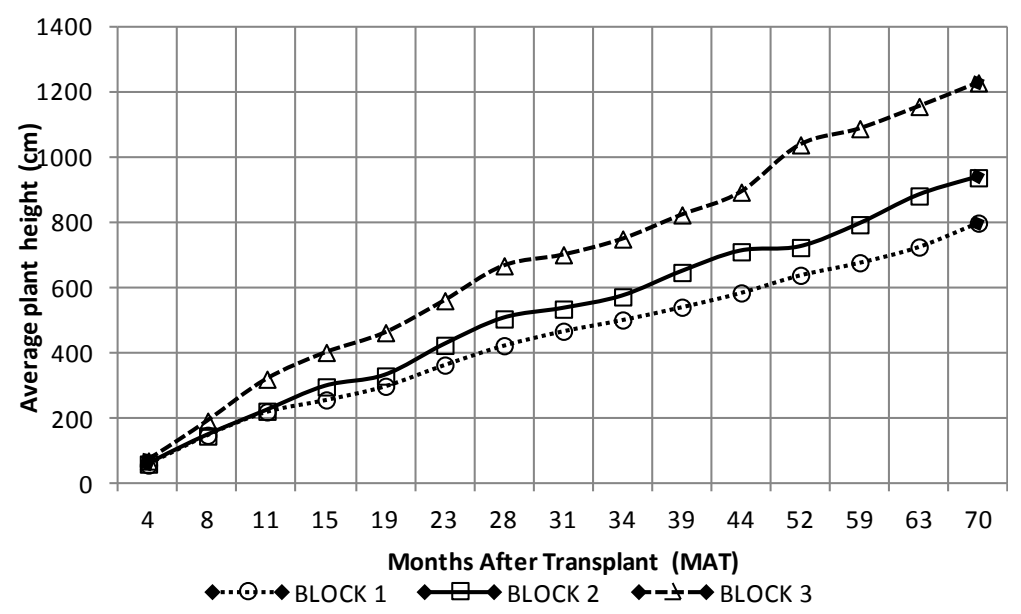

(a)

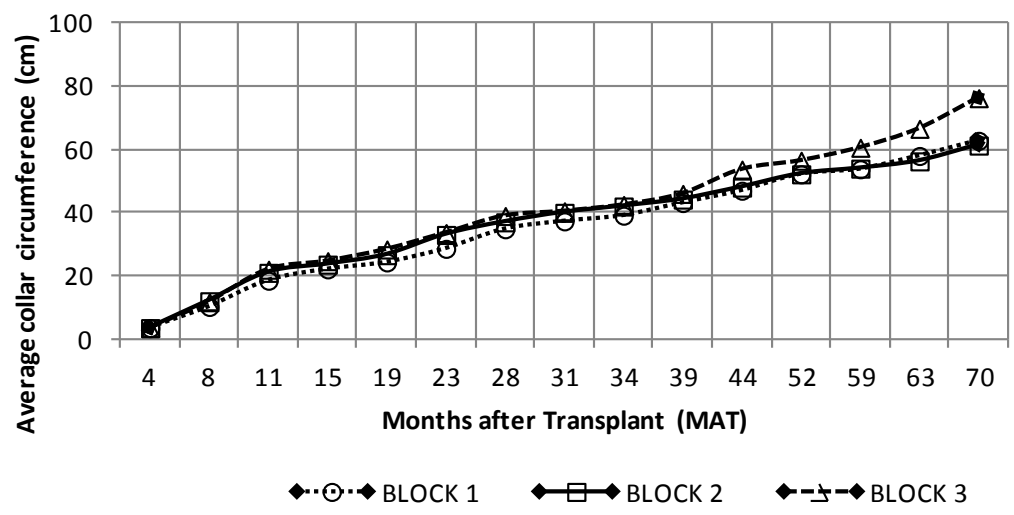

(b)

Figure 5. Study of the growth curves with respect to the various geomorphic surfaces (experiment): (a) Variation of height in each block, (b) variation of collar circumference in each block for the experiment. NB: Each point is the mean of six plants. Based on averages, plant height increase at the rate of $14.66 \mathrm{~cm} /$ month, $16.55 \mathrm{~cm} / \mathrm{month}$ and 21.99 $\mathrm{cm} /$ month in blocks 1,2 and 3, respectively, while collar circumference increase at the rate of $1.16 \mathrm{~cm} /$ month, $1.22 \mathrm{~cm} /$ month and $1.30 \mathrm{~cm} /$ month in blocks 1,2 and 3, respectively. 


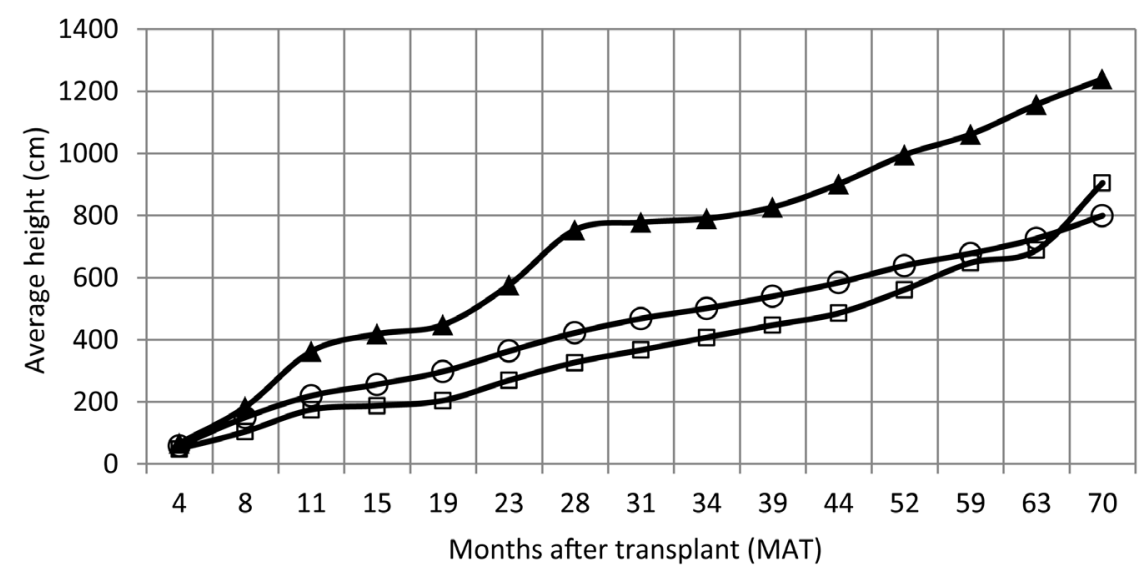

Block 1

—Block 2

$\longrightarrow$ Block 3

(a)

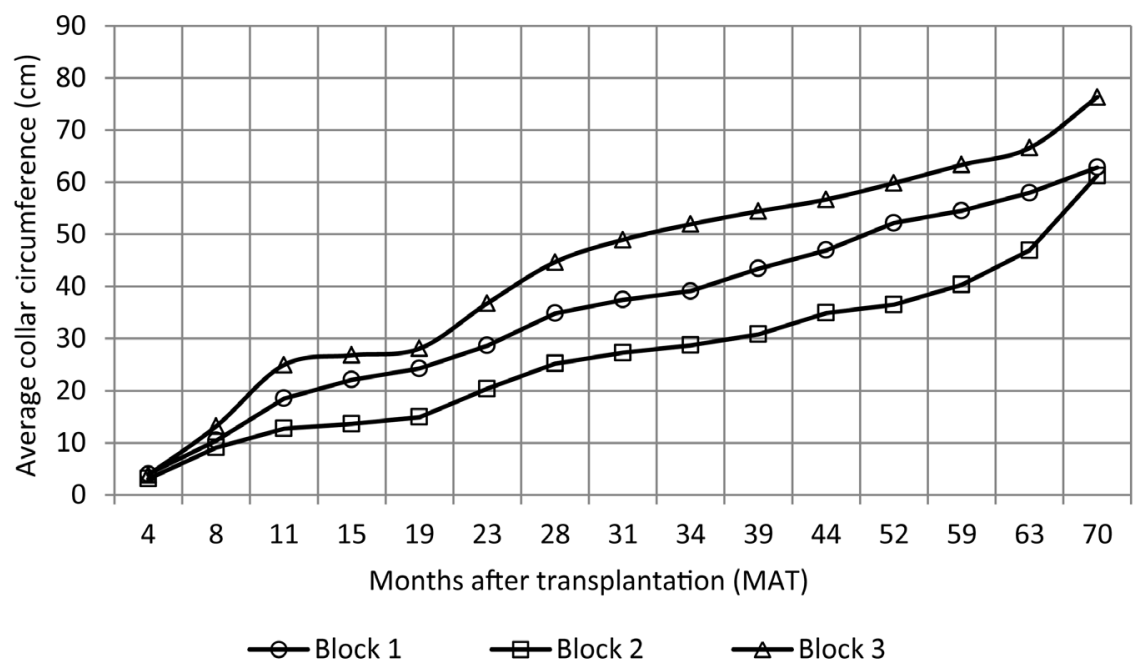

(b)

Figure 6. Study of the growth curves with respect to the various geomorphic surfaces (control): (a) Variation of height in each block, (b) variation of collar circumference in each block for the control. NB: Each point is the mean of six plants. Based on averages, plant height increase at the rate of $14.72 \mathrm{~cm} /$ month, $11.98 \mathrm{~cm} / \mathrm{month}$ and 22.63 $\mathrm{cm} /$ month in blocks 1,2 and 3 , respectively, while collar circumference increase at the rate of $1.167 \mathrm{~cm} /$ month, $0.86 \mathrm{~cm} /$ month and $1.43 \mathrm{~cm} /$ month in blocks 1,2 and 3, respectively.

the experiment. For the control, plant height averages increase at the rate of $14.72 \mathrm{~cm} /$ month, $11.98 \mathrm{~cm} /$ month and $22.63 \mathrm{~cm} /$ month in blocks 1,2 and 3, respectively. The increase in height followed the geomorphic surface from upper slope (shoulder) to foot slope (Figures 7-9). Statistically, growth in blocks 1 and 2 are similar and significantly different from that in block 3 (p-value 0.05 ). For the collar circumference, average collar circumferences attained were $62.8,61.3$, and $76.3 \mathrm{~cm}$ in blocks 1,2 , and 3, respectively for the experiment. For the control, maximum collar circumferences attained were: $61.3 \mathrm{~cm}, 62.8 \mathrm{~cm}$ and 76.3 $\mathrm{cm}$ for block 1, 2 and 3, respectively. Collar circumferences were shown to increase at the rate of $1.16 \mathrm{~cm} /$ month, $1.22 \mathrm{~cm} /$ month and $1.30 \mathrm{~cm} /$ month in 


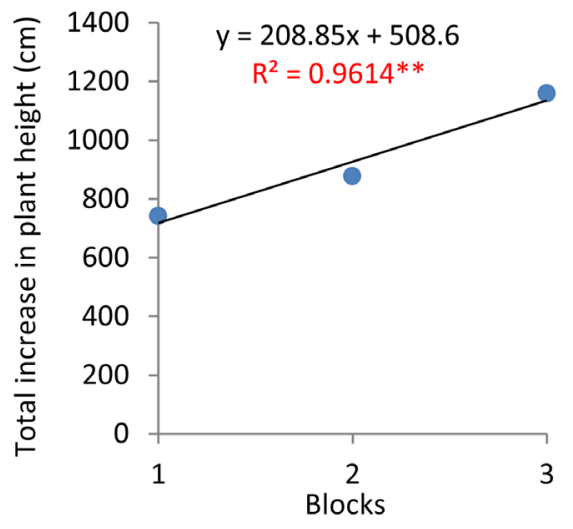

(a)

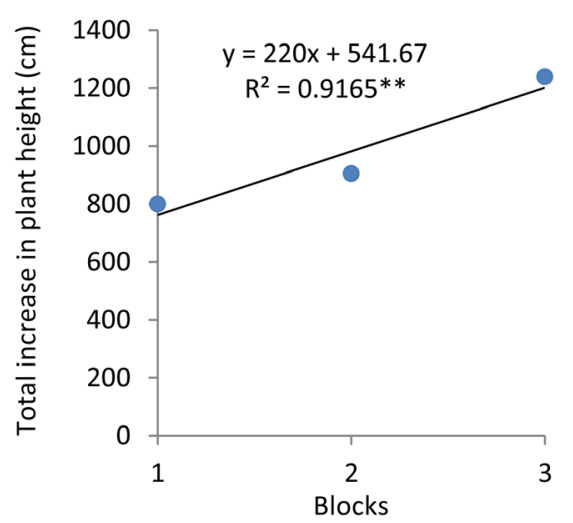

(b)

Figure 7. Linear relationship between geomorphic surface and total increase in plant height: (a) Experiment; (b) Control. NB: ${ }^{\star}$ Significant at 0.01 level of confidence.

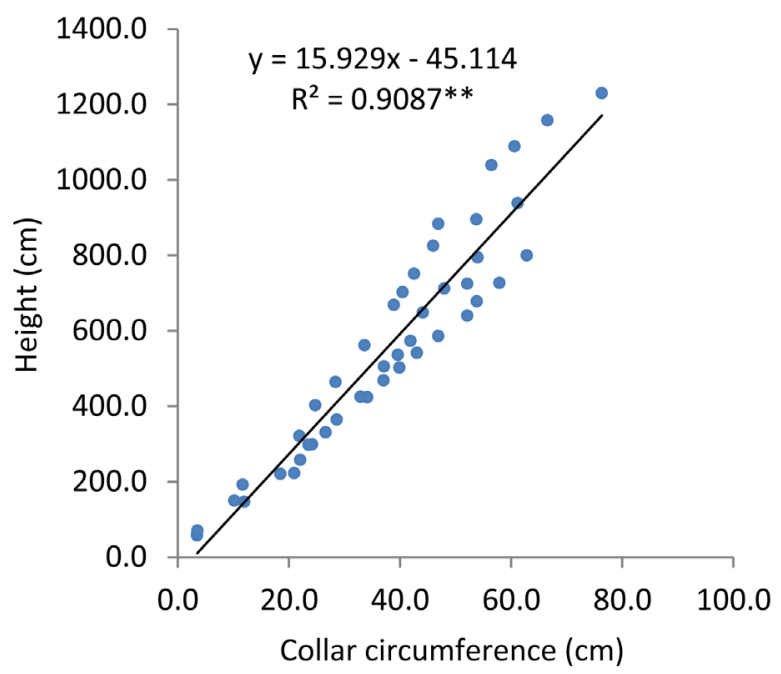

(a)

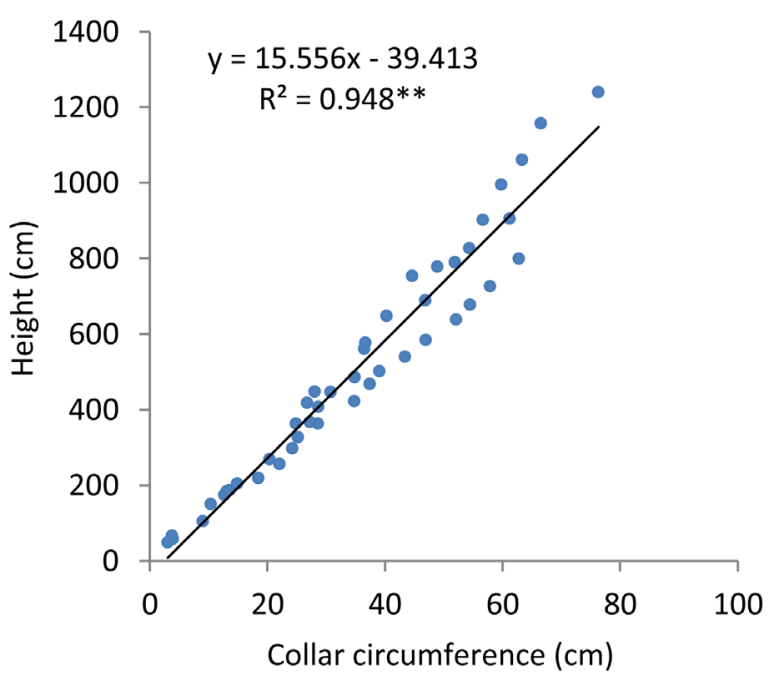

(b)

Figure 8. Linear relationship between total increase in plant height and total increase in collar circumference: (a) Experiment; (b) Control. NB: ${ }^{\star \star}$ Significant at 0.01 level of confidence. 


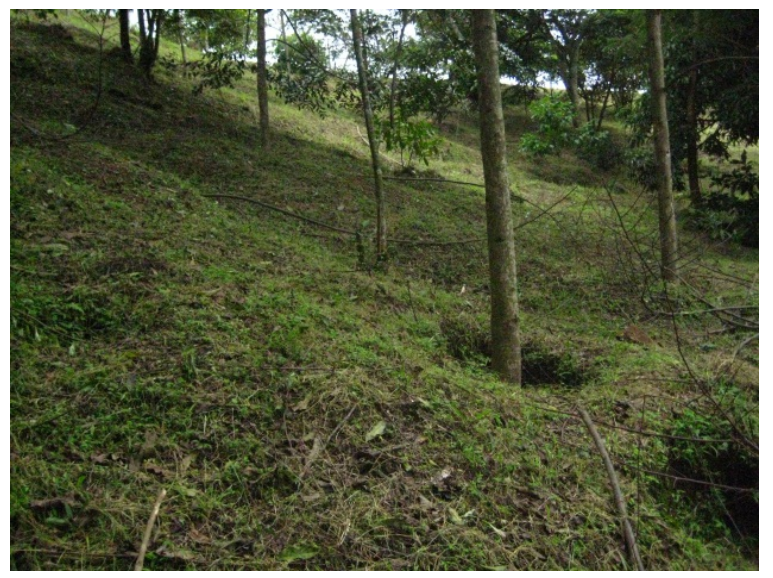

Figure 9. Maesopsis plant at right in hole. Note that plant circumference decrease as you move uphill.

blocks 1,2 and 3, respectively for the experiment and $1.167 \mathrm{~cm} /$ month, 0.86 $\mathrm{cm} /$ month and $1.43 \mathrm{~cm} /$ month in blocks 1,2 and 3, respectively for the control.

The analysis of variance (ANOVA) indicated that geomorphic surface had a significant effect on plant height at a p-value of 0.05 , but had no effect on collar circumference. For the control, the ANOVA indicated that geomorphic surface had an effect on both height and collar circumference at the 0.05 confidence level. Correlations between growth parameters were significant for both the experiment and the control but were higher in the control (Figure 8) at a p-value of 0.01 .

The effect of blocks (geomorphic surface) on growth of Maesopsis is presented in Table 2.

\section{Discussions}

\subsection{Contribution of Soil Properties to the Growth of Maesopsis}

From the results of the analytical data it is evident that the soils under which these plants have evolved are generally poor in nutrients and are acidic in nature as they have developed from granitic parent materials $\left(\mathrm{pH}_{\left(\mathrm{H}_{2} \mathrm{O}\right)} 4.8\right.$ - 5.9) [22]. They also have considerable amounts of exchangeable aluminium (Al), which would fix phosphorous $(\mathrm{P})$ and reduce its availability to plants.

Equally, the increasing bulk densities with depth (from 0.88 at the surface to $1.5 \mathrm{~g} / \mathrm{cm}^{3}$ in subsurface horizons) indicate increasing soil compaction that would have great impact on root penetration. Very low hydraulic conductivity values, especially in blocks 1 and 2, indicate limited water infiltration rates and likely plant moisture stress, especially during the dry season.

Description of the soil profiles indicate that these soils are made up of two main orders: Entisols at the upper and middle slopes; Inceptisols occupy lower slope environments. The decreasing percent slope downwards is correlated with increasing soil depth for root exploration and increased water and nutrient holding capacity which both have increasing positive effects on plant growth (Figure 10 and Figure 11). In this area in the natural state, the climax vegetation 


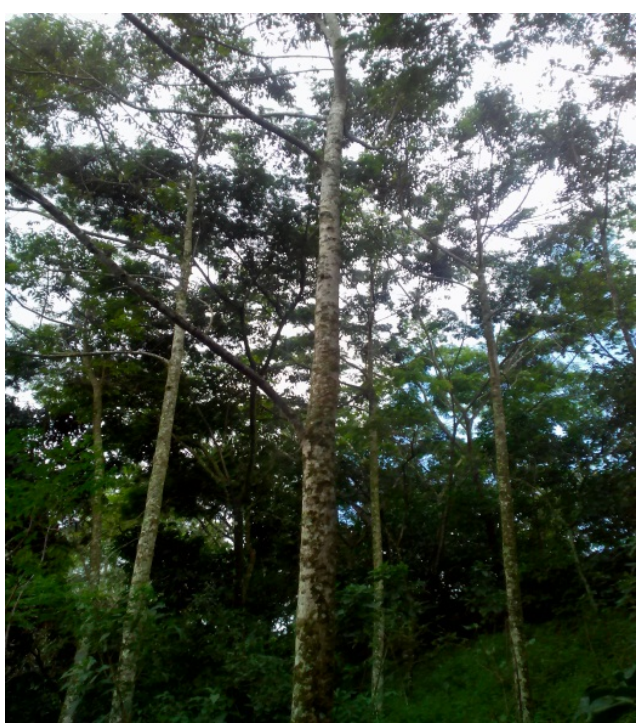

Figure 10. Maesopsis experiment at foot slope, with some in-situ plants in the back ground. Note the very tall nature of the plants.

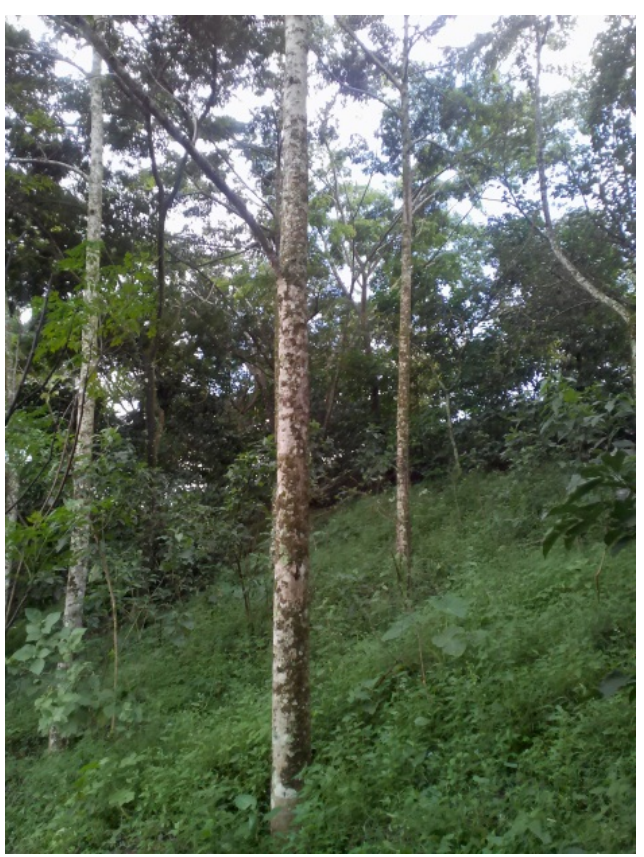

Figure 11. Maesopsis experiment pictured from the lower slope. Note decreasing height and circumference as one goes up slope.

goes from forest at the lower foot slope to forest savanna to savanna towards the top of the slope. However, with soil profile modification, which increases nutrients through decomposed mulch and profile depth through "induced hydrolysis" ensures that the upper slopes which naturally are under grass can support forest vegetation also. The near similarities in the growth parameters across varying slope environments from top slope to bottom slope indicates the efficiency of the profile modification technique applied and suggests that this technique 
would be invaluable for forest regeneration in steeply sloping areas. This indicates that Maesopsis is a tolerant and fast growing species which is not very demanding and which can do well on varied slope terrains where profile modification is made and when micro-basins are established under the plants (Figure 9). At the upper slope, the presence of concretions observed at depths of $80 / 85 \mathrm{~cm}$ and $114 / 120 \mathrm{~cm}$ could have been a limitation to the growth of the plants in the long run as this might act as a hindrance to root penetration into the soil. Plant roots being stressed in this manner will generally retard in growth. At the middle slope, though very steep $(<45 \%)$, growth of plants is favored probably by the fact that the soils developed under natural conditions (no compaction due to anthropic activities as in block 1-upper slope) and further fostered by the establishment of micro-basins and profile modification, a process whereby large holes retain water and allow same to percolate into the ground slowly, resulting in the chemical attack of the rock facilitating root penetration (1). These micro-basins enhance the amount of water collected which then acts through "induced hydrolysis", a terminology coined to describe this process at Yongka research park, that explains the enhancement of chemical weathering process whereby the soil profile develops downwards or better still makes the soils deeper. This enables the best growth of Maesopsis resulting from soil nutrients from weathered rock materials, and the much deeper soil profile which enhances root penetration and exploration for water and nutrients.

\subsection{Correlation of Geomorphic Surface with the Growth of Maesopsis}

There exists a strong correlation between geomorphic surface and total increase in plant height (Figure 7). As seen from the correlation and regression analyses (Figure 7 and Figure 8), the Pearson's correlation test shows that there exist a strong correlation between geomorphic surface and height and between growth parameters (height and collar circumference). Regression analysis shows that there exist a linear relationship between blocks and total increase in plant height. That is, as we move from block 1 to 3 (from upslope to foot slope), plant height increases following the regression equation $\mathrm{Y}=208.85 \mathrm{X}+508.6, \mathrm{R}^{2}=0.9614$ (this is significant at 0.01 level of confidence). There also exists a linear relationship between total increase in plant height and total increase in collar circumference: as plant height increases, collar circumference increases as well following the regression equation $\mathrm{Y}=9.983 \mathrm{X}+294.63, \mathrm{R}^{2}=0.3613$ for the experiment, and $\mathrm{Y}=220 \mathrm{X}+541.67, \mathrm{R}^{2}=0.9165$ for the control (significant at 0.01 confidence level). These relationships can be used to predict plant growth potential when profile modification and micro-basin techniques are applied.

\subsection{Contributions of Soil Management Practices to the Growth of Maesopsis}

The application of the profile modification technique by making of holes with dimensions $70 \times 70 \times 70 \mathrm{~cm}$ is a favorable practice for the growth of the plants at 
an early stage as roots can easily penetrate in the soil-thus plants are stress free. The soil also favors water and nutrient retention. The presence of mulch contributes to the amelioration of the soil structure, preventing erosion, reducing evaporation of water from soil and providing biomass for organic matter production at the surface which is an important component of soil fertility upon decomposition. The increased amount of water retained in the holes, with limited evaporation due to the mulched surface, slowly infiltrates into the soil and attacks the rock through the process which has been termed here "induced hydrolysis". This process resulting in a systematic weathering of the rock enhances root penetration as the weathered rocks also provide nutrients for plant development.

\section{Conclusions}

Maesopsis eminii is a fast growing species which is not very demanding in terms of nutrients, and which can grow well on varied slope terrains. Results of this study indicate that geomorphic surface has an effect on height of Maesopsis. Trees with greatest heights are obtained at foot slopes while less tall trees are obtained at upper slopes and middle slopes. Foot slopes with greater soil depths provide better environments for root evolution. For purposes of watershed conservation, Maesopsis is a very good species and can be planted on various geomorphic surfaces provided profile modification with holes of dimensions of at least $70 \times 70 \times 70 \mathrm{~cm}$ (to enhance water retention and root penetration) and mulching (initially to suppress water evaporation and ultimately to serve as an organic fertilizer after decomposition) are established. Through profile modification and micro-basins, rock weathering is enhanced through induced hydrolysis' leading to softer rock more easily penetrated by the tap root.

For purposes of timber, planting is best at the foot slope so as to obtain tall trees faster. For other purposes (as mentioned in the introduction), Maesopsis can be planted anywhere following the geomorphic surface. The results of this study are thus highly recommended for forest regeneration in grass field areas such as the Western Highlands of Cameroon and similar ecological areas where Entisols and Inceptisols with shallow profiles exist. Maesopsis is a fast growing plant species; its planting is recommended for those who will use it as fuel wood. For timber purposes, the time for a given tree height and circumference to be attained can be estimated thereby enabling good planning and management. Because of the fast growth, Maesopsis is also strongly recommended for watershed protection as it will enhance the recharge of the water table thereby increasing water yields. Maesopsis is recommended for carbon sequestration because of its fast growing rate. Finally, its medicinal value that is yet little exploited constitutes more compelling arguments for its cultivation.

\section{Acknowledgements}

We thank the authorities of Yongka Western Highlands Research Garden Park for creating an enabling environment for this work to be carried out. 


\section{References}

[1] Yerima, B.P.K. (2010) Protective Measures Taken for Preserving Species Endangered of Extinction Due to the Climate Change in Yongka Western Highlands Research Garden-Park, Nkwen-Bamenda, NW Region, Cameroon. Support Africa International, 4-11.

[2] Egger, K. (1986) Ecological Intensification. Soil Conservation and Improvement of Tropical Soils by Pastoral Agroforestry Systems. Collection Documents Systèmes Agraires, 6, 129-135.

[3] Walters, S.J., Christopher, S.C., Kellogg, E.A. and Stevens, P.F. (1999) Plant Systematics.

[4] Jøker, D. (2000) Maesopsis eminii-48. Seed Leaflet, No. 48.

[5] Aubreville, A. (1959) La flore forestière de la Cote d'Ivoire, 2nd Edition, 3 Vols., Centre Technique Forestier Tropical, Nogent-sur-Marne.

[6] Buchholz, T. (2003) Silvicultural Potential of Maesopsis eminii in Uganda. I-TOO Working Paper No. 12.

[7] Büttner, S. (2004) Seed Source, Seed Size and Seed Sowing Technique of Maesopsis eminii in Uganda-A Study on Improved Nursery Management. I-TOO Working Paper No. 16.

[8] Hallé, N. (1962) Rhamnacées. Flore du Gabon, 4, 49-52.

[9] Orwa, C., Mutua, A., Kindt, R., Jamnadass, R. and Anthony, S. (2009) Agroforestry Database: A Tree Reference and Selection Guide Version 4.0. World Agroforestry Centre, Kenya.

[10] Santesson, C.G. (1926) Some Medicinal Plants from Cameroon and Their Utilizations by the Local Population. Archives of Botany, 20, 1-34.

[11] Noumi, E. and Tchakonang, N.Y.C. (2001) Plants Used as Abortifacient in the Sangmelima Region of Southern Cameroon. Journal of Ethnopharmacology, 76, 263-268. https://doi.org/10.1016/S0378-8741(01)00252-5

[12] Ainslie, J.R. (1937) List of Plants Used in Native Medicine in Nigeria. Institute Paper 7, Imperial Forestry Institute, Oxford University, Oxford.

[13] Irvine, F.R. (1961) Woody Plants of Ghana, with Special Reference to Their Uses. Oxford University Press, London.

[14] Harborne, J.B. and Baxter, H. (1993) Phytochemical Dictionnary and Handbook of Bioactive Compounds from Plants. Taylor and Francis, London.

[15] Alves, T.M., Nagem, T.J., De Carvalho, L.H., Krettli, A.U. and Zani, C.L. (1997) Antiplasmodial Triterpene from Vernonia brasiliana. Planta Medica, 63, 554-555. https://doi.org/10.1055/s-2006-957764

[16] Geetha, T. and Varalakshmi, P. (1998) Anti-Inflammatory Activity of Lupeol Linoleate in Adjuvant Induced Arthritis. Fitoterapia, 69, 13-19.

[17] Fokou, P.A. (2006) Chemical Investigation of Three Plants Used in Cameroonian Traditional Medicine: Maesopsis eminii (Rhamnaceae), Autranella congolensis (Sapotaceae) and Pentadesma grandifolia (Guttiferae). PhD Thesis, Bielefeld University, Bielefeld.

[18] Fokou, P., et al. (2004) Triterpenes from Maesopsis eminii. Journal of Natural Products, 67, 2124-2126. https://doi.org/10.1021/np0497548

[19] Soil Conservation Service (1984) Soil Survey Laboratory Methods and Procedures for Collecting Soil Samples. Soil Survey Invest. Rep. No. 1, US Gov. Print. Office. Washington DC.

[20] Klute, A. and Dirksen, C. (1986) Hydraulic Conductivity and Diffusivity: Labora- 
tory Methods. In: Klute, A., Ed., Methods of Soil Analysis. Part 1: Physical and Miner Alogical Methods, 2nd Edition, Agronomy Monograph No. 9, ASA, Madison, 687-734. https://doi.org/10.2136/sssabookser5.1.2ed.c28

[21] Yerima, B.P.K. (2008) Prototype for Watershed Management and Biodiversity Conservation in the Degraded Western Highland Regions of Cameroon. Published under the Conference Sub-Themes: 4-Analysing the Multi-Functional Nature of Complex Commons. Study of the Commons, Gloucester.

[22] Yerima, B.P.K. and Van Ranst, E. (2005) Introduction to Soil Science: Soils of the Tropics. Trafford Publishing, Bloomington.

Submit or recommend next manuscript to SCIRP and we will provide best service for you:

Accepting pre-submission inquiries through Email, Facebook, LinkedIn, Twitter, etc. A wide selection of journals (inclusive of 9 subjects, more than 200 journals) Providing 24-hour high-quality service User-friendly online submission system Fair and swift peer-review system Efficient typesetting and proofreading procedure Display of the result of downloads and visits, as well as the number of cited articles Maximum dissemination of your research work

Submit your manuscript at: http://papersubmission.scirp.org/ Or contact ajps@scirp.org 